\title{
First report of Onion yellow dwarf virus and Allexivirus associated with noble garlic in Itajai Valley, Santa Catarina State, Brazil
}

\author{
Edivânio Rodrigues de Araújoㅜ; Fábio Satoshi Higashikawa ${ }^{1}$; Mirtes Freitas Lima²
}

${ }^{1}$ Epagri/Estação Experimental de Ituporanga, Estrada Geral Lageado Águas Negras, 453, CEP: 88400-000, Ituporanga-SC, Brazil. ${ }^{2}$ Embrapa Hortaliças, Rodovia BR-060, Km 09 (Brasília/Anápolis), Fazenda Tamanduá, CEP: 70275-970, Brasília-DF, Brazil.

Autor para correspondência. Edivânio Rodrigues de Araújo (edivanioaraujo@epagri.sc.gov.br)

Data de chegada: 04/04/2017. Aceito para publicação em: 04/11/2017.

$10.1590 / 0100-5405 / 178028$
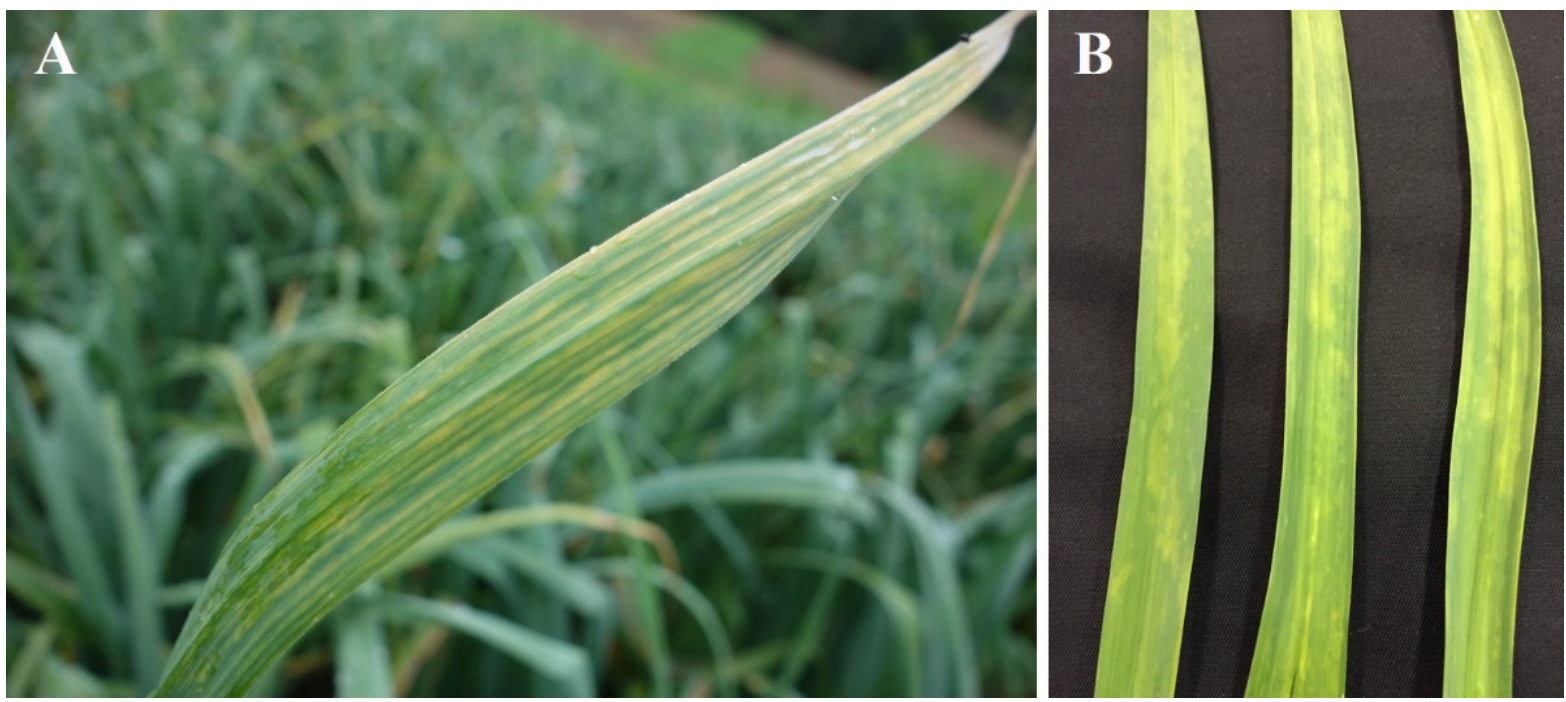

Figure 1. Symptomatic leaves of garlic (Allium sativum L.) plants exhibiting yellowing mosaic caused by viruses, 29 days after planting, collected at Epagri/Ituporanga Experimental Station, Itajai Valley, Santa Catarina, Brazil. A - Symptoms on leaves of infected plants observed in the field. B - Symptomatic leaves collected from virus-infected plants for diagnosis.

Garlic (Allium sativum L.) is the second most economically important Allium species in Brazil, which produced 130.4 thousand tons in 2016. The state of Santa Catarina (SC) contributed with approximately $20 \%$ of this production (4). In the country, planting of noble garlic started in SC in 1970. Nowadays, SC stands out as the second largest national garlic producer, after the state of Minas Gerais (4). Due to vegetative propagation, several virus species, including members of Potyvirus, Potyviridae (Leek yellow stripe virus - LYSV; Onion yellow dwarf virus - OYDV), Allexivirus, Alphaflexiviridae (Garlic mite-borne filamentous virus - GaMbFV; Garlic virus A - GarV-A; Garlic virus B - GarV-B; Garlic virus $C$ - GarV-C; Garlic virus D - GarV-D) and Carlavirus, Betaflexiviridae (Garlic common latent virus - GarCLV; Shallot latent virus - SLV) became a constraint on garlic production worldwide. In general, potyviruses have been most frequently detected (5). Potyviruses and carlaviruses are transmitted to garlic by aphids in a non-persistent manner, while mites transmit allexiviruses (9). However, vegetative propagation is the main mechanism that accounts for virus dissemination in garlic, perpetuating them over generations (7). Despite the relevance of SC to the national garlic production, few studies have dealt with the detection of virus in garlic fields in this state. In 1989, Garlic yellow streak virus (Potyvirus) was identified in $100 \%$ garlic seeds collected in SC (8). However, in 1994, analysis performed on 33 samples collected across different Brazilian states, including SC, indicated that garlic plants were infected by potyviruses and carlaviruses (2). It is noteworthy that there is no available information on viruses associated with garlic in the Itajai Valley region. Therefore, this study represents a contribution to the knowledge of virus occurrence in garlic fields in this region.

Plants of noble garlic, cultivars Ito and Quitéria, exhibiting yellow mosaic symptoms on the leaves, were observed in fields at Epagri/ Ituporanga Experimental Station, Itajai Valley, SC, Brazil, in 2016, 29 days after sowing (Figures 1A and 1B). Symptomatic plants were randomly sampled, and 27 leaf samples were collected from cv. Ito and 21 from cv. Quitéria. Samples were analyzed at the Laboratory of Virology and Molecular Biology of Embrapa Vegetables, Brasília, Brazil. Serological tests were performed using both antibodies against Iris yellow spot virus (IYSV), Onion yellow dwarf virus (OYDV) and common antibodies against allexiviruses (Garlic virus $B$ - GarV-B, Garlic virus C - GarV-C and, Garlic virus D - GarV-D), by NCM-ELISA (Nitrocellulose Membrane-Enzyme-linked immunosorbent assay) (1).

Onion yellow dwarf virus (OYDV) was detected in 18.5\% and $38 \%$ samples collected from cultivars Ito and Quitéria, respectively. Samples also tested positive against allexiviruses general antibodies, 3.7\% for cv. Ito and $4.7 \%$ for cv. Quitéria. Only one sample collected from cv. Ito $(3.7 \%)$ presented mixed infection (OYDV and allexiviruses). Iris yellow spot virus was not detected (Figure 2).

OYDV and allexiviruses (mostly Garlic virus $C$ - GarV-C and Garlic mite-borne filamentous virus - GarMbFV) have already been 


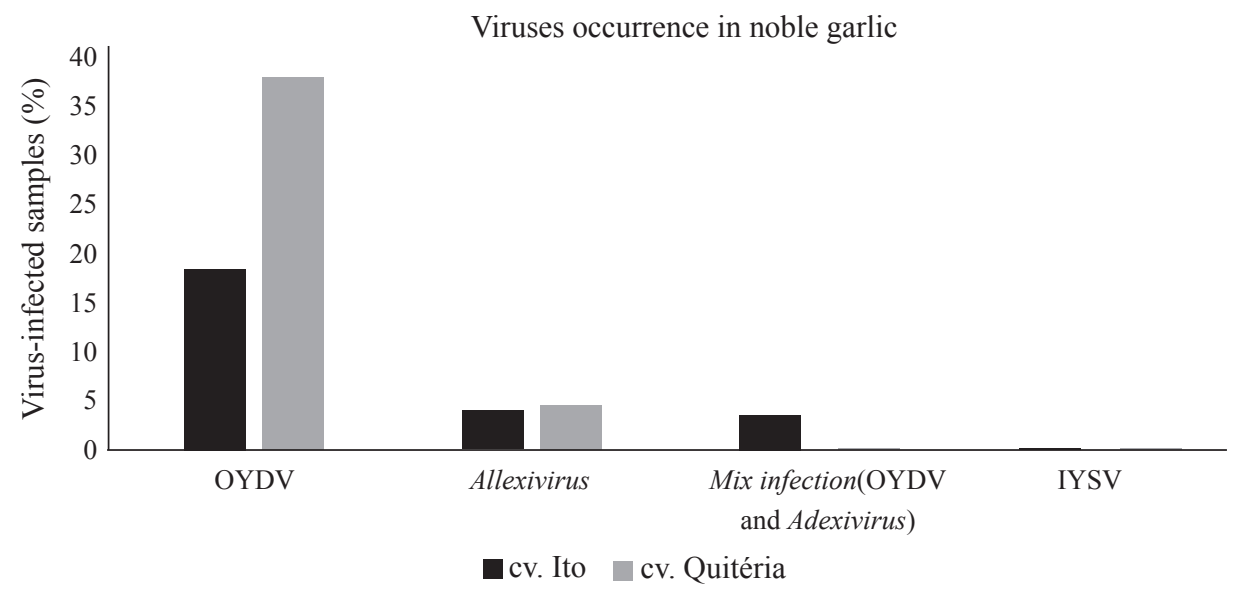

Figure 2. Occurrence of Onion yellow dwarf virus (OYDV), species of Allexivirus genus (common antibodies for Garlic virus B - GarV-B, Garlic virus $C$ - GarV-C, and Garlic virus D - GarV-D detection), and Iris yellow spot virus (IYSV) in field-grown plants of two garlic (Allium sativum L.) cultivars (Ito and Quitéria) showing leaf yellowing mosaic symptoms, collected at Epagri/Ituporanga Experimental Station, Itajai Valley, Santa Catarina, Brazil.

reported to occur in garlic fields of four Brazilian regions, represented by the states of Goiás, Minas Gerais, Bahia and Rio Grande do Sul (3). Similarly, in another study on garlic viruses, OYDV (56\% samples) and LYSV (55\%) were the most frequent potyviruses detected, while GarV-A (29\% samples) and GarV-D (28\%) were predominant among allexiviruses in fields sampled from the states of Goiás, Minas Gerais, Paraná and São Paulo (6). No garlic fields from the state of SC were included in those virus surveys.

The occurrence of garlic viruses in Itajai Valley region may be due to the planting of infected seeds, as well as to transmission by aphid or mite vectors in the field (10). Growers in Itajai Valley should be alert to the presence of OYDV, the main virus infecting garlic worldwide, since that region also has high concentration of onion production, another host for the virus (11). To our knowledge, this is the first report on the detection of allexiviruses associated with garlic in Santa Catarina State.

\section{REFERENCES}

1. Clark, M.F.; and Adams, A.N. Characteristics of the microplate method of Enzyme-Linked Immunosorbent Assay for the detection of plant viruses. Journal of General Virology, Londres, v. 34, n. 3, p. 475-483, 1977.

2. Dusi, A.N.; Fajardo, T.V.M.; Cupertino, F.P. Serological identification of garlic (Allium sativum L.) viruses in Brazil. Fitopatologia Brasileira, v.19 (supl.), p. 298, 1994.

3. Fayad-André, M.S.; Dusi, A.N.; Resende, R.O. Spread of viruses in garlic fields cultivated under different agricultural production systems in Brazil.
Tropical Plant Pathology, Brasília, v. 36, n. 6, p. 341-349, 2011.

4. IBGE. Levantamento Sistemático da Produção Agrícola Rio de Janeiro, v. 30, n. 1, p.1-81, janeiro, 2017.

5. Katis, N.I.; Maliogka, V.I.; Dovas, C.I. Viruses of the genus Allium in the Mediterranean region. In: Loebenstein, G.; and Lecoq, H. (Eds.) Viruses and Virus Diseases of Vegetables in the Mediterranean Basin. San Diego, CA, USA. Elsevier. pp. 163-208, 2012.

6. Mituti, T.; Moura, M.F.; Marubayashi, J.M.; Oliveira, M.L.; Imaizumi, V.M.; Krause-Sakate, R.; Pavan, M.A. Survey of viruses belonging to different genera and species in noble garlic in Brazil. Scientia Agricola, Piracicaba, v. 72 , n. 3, p. 278-281, 2015.

7. Oliveira, M.L.; Nardini, J.P.C.; Marchi, B.R.; Mituti, T.; Bampi, D.; Pavan, M.A.; Krause-Sakate, R. Análise da presença de vírus em alho semente da segunda e quarta gerações, produzidos por termoterapia e cultura de tecido. Summa Phytopathologica, Botucatu, v.40, n. 1, p. 75-77, 2014.

8. Pavan, M.A.; Guimarães, A.M.; Kamitsuji, M.K.; Matsumoto, S.N. Amostrs agem da incidência de viroses em cultivares de alho nobre (Allium sativum L.) provenientes em regiões produtoras do estado de Santa Catarina. Fitopatologia Brasileira, v.14 (supl.), p. 136, 1989.

9. Perotto, M.C.; Di Rienzo, J.A.; Lanati, S.; Panonto, S.; Macchiavelli, R.; Cafrune, E.E.; Conci, V.C. Temporal and spatial spread of potyvirus infection and its relationship to aphid populations visiting garlic crops. Australasian Plant Pathology, Berlim, v. 43, n. 6, p. 623-630, 2014.

10. Salomon, R. Virus diseases in garlic and the propagation of virus-free plants. In: Rabinowitch, H.; and Currah, L. (Eds.). Allium Crop Science: Recent Advances. New York, CABI, pp. 311-327, 2002.

11. Verma, R.K.; Mishra, R.; Petrov, N.M.; Stoyanova, M.; Stoev, A.; Bakardjieva, N.; Gaur, R.K. Molecular characterization and recombination analysis of an Indian isolate of Onion yellow dwarf virus. European Journal of Plant Pathology, Berlim, v. 143, n. 3, p. 437-445, 2015. 